\title{
Regulation of the degradative pathways from 4-toluenesulphonate and 4-toluenecarboxylate to protocatechuate in Comamonas testosteroni T-2
}

\author{
Hans R. Schläfli Oppenberg, ${ }^{1} \dagger$ Gang Chen, ${ }^{1} \ddagger$ Thomas Leisinger ${ }^{1}$ and \\ Alasdair M. Cook ${ }^{1,2}$
}

Author for correspondence: Alasdair M. Cook. Tel: +49 753188 4247. Fax: +497531 882966. e-mail: Alasdair.Cook@uni-konstanz.de

\footnotetext{
1 Microbiology Institute, Swiss Federal Institute of Technology, ETH-Zentrum, CH-8092 Zürich, Switzerland

2 Fakultăt fü Biologie der Universităt, Postfach 5560 M649, D-78434 Konstanz, Germany
}

\begin{abstract}
Comamonas testosteroni T-2 was grown in salts medium containing intermediates of the established, inducible degradative pathway(s) for 4-toluenesulphonate/4-toluenecarboxylate. The specific activity or, if appropriate, the specific expression of pathway enzymes or their components was constant throughout growth and decreased only slowly in the stationary phase. It was found that the 4-toluenesulphonate methyl-monooxygenase system and 4-sulphobenzyl alcohol dehydrogenase (with 4sulphobenzaldehyde dehydrogenase) were always co-induced, with similar ratios of their activities during growth with 4-toluenesulphonate, 4toluenecarboxylate and 4-sulphobenzoate. We presume these enzymes to be co-expressed from one regulatory unit. The ratio of activities of the terephthalate 1,2-dioxygenase system to those of $(1 R, 25)$-dihydroxy-1,4dicarboxy-3,5-cyclohexadiene dehydrogenase was also constant, and present only during growth with 4-toluenecarboxylate or terephthalate. We presume these two enzymes to be co-expressed from a different regulatory unit. The oxygenase component of 4-sulphobenzoate 3,4-dioxygenase (PSBDOS) was expressed at high levels in most growth conditions examined, the exception being with 4-toluenecarboxylate as carbon source. However, no expression of a specific reductase activity linked to synthesis of the oxygenase of PSBDOS could be detected. The PSBDOS was thus active in vivo solely under conditions where the 4-toluenesulphonate methyl-monooxygenase system was also present, whose reductase is active with the oxygenase of the 4 sulphobenzoate 3,4-dioxygenase system in vitro, and, apparently, in vivo. The synthesis of PSBDOS is thus under the control of a third regulatory unit.
\end{abstract}

Keywords: Comamonas testosteroni, regulation of aromatic catabolism, oxygenase systems, $p$-toluenesulphonate, $p$-toluate

\section{INTRODUCTION}

Comamonas testosteroni T-2 utilizes 4-toluenesulphonate or its non-sulphonated analogue, 4-toluenecarboxylate $(p$ -

†Present address: Fa. Paul Bucher, CH-4051 Basel, Switzerland.

łPresent address: Friedrich Miescher Institut, Postfach 2543, CH-4002 Basel, Switzerland.

Abbreviations: DCDDH, (1R,2S)-dihydroxy-1,4-dicarboxy-3,5-cyclohexadiene dehydrogenase; SOLDH, 4-sulphobenzyl alcohol dehydrogenase; SYDDH, 4-sulphobenzaldehyde dehydrogenase; PC45O, protocatechuate 4,5-dioxygenase; PSBDOS, p-sulphobenzoate 3,4-dioxygenase system; TERDOS, terephthalate 1,2-dioxygenase system; TSMOS, 4-toluenesulphonate methyl-monooxygenase system. toluate) as sole source of carbon and energy for growth (Fig. 1) (Locher et al., 1989, 1991c; Thurnheer et al., 1986). Toluenesulphonate, at least, is taken up by a specific and inducible transport system (Locher et al., 1993), and the catabolic enzymes are inducible (Locher $e t$ al., 1989, 1991c). In the cell, metabolism of toluenesulphonate and toluate is initiated by the same enzyme, the 4-toluenesulphonate methyl-monooxygenase system (TSMOS), which consists of a monomeric reductase (component B) and a homomultimeric oxygenase (component $M$ ), to yield 4-sulphobenzyl alcohol and 4carboxybenzyl alcohol, respectively (Locher $e t$ al., 1991b). 4-Sulphobenzylalcohol dehydrogenase, SOLDH, oxi- 


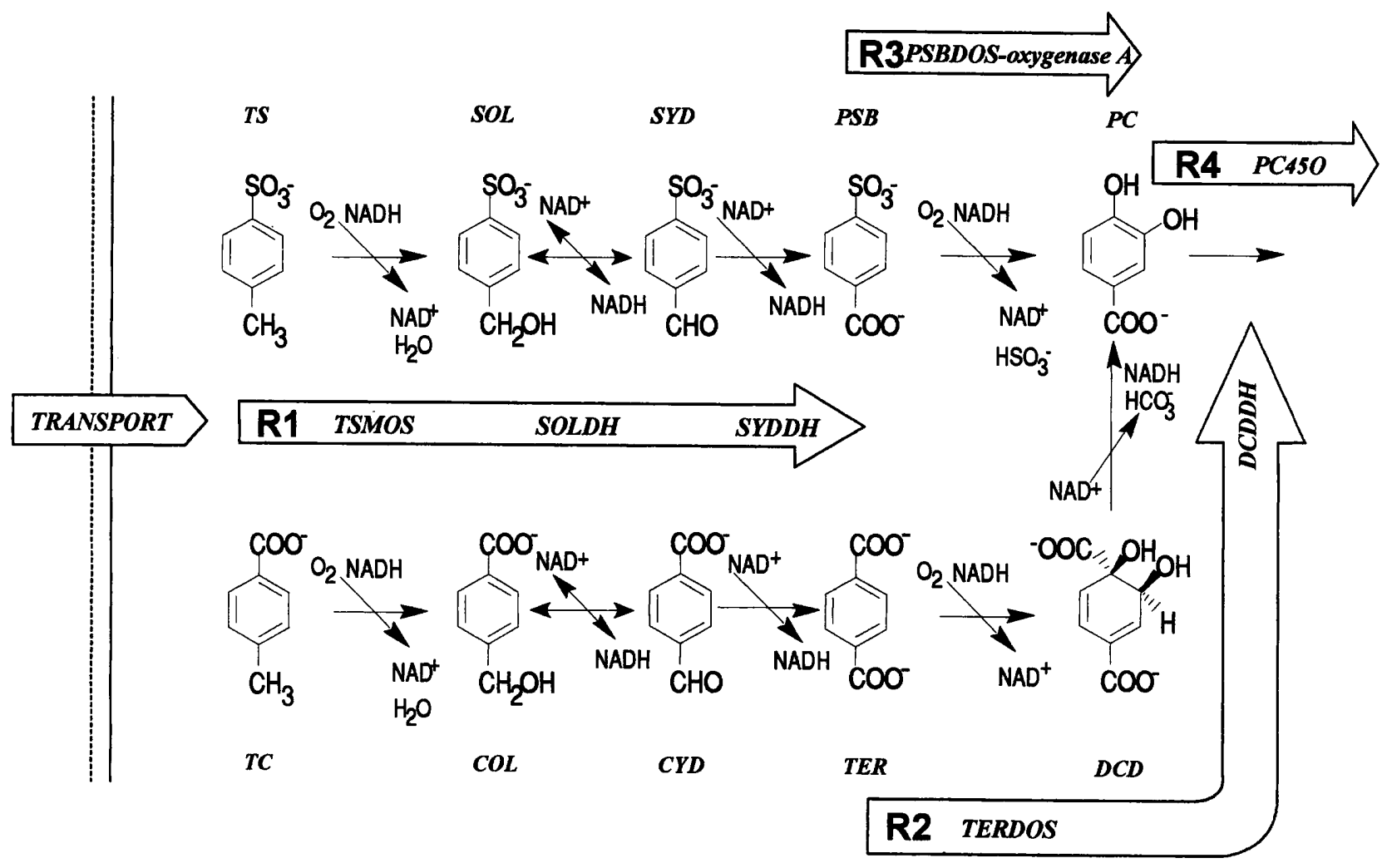

Fig. 1. Transport and degradation of toluenesulphonate and toluate in $C$. testosteroni $T-2$, and the regulatory units deduced from this work (R1-R4). The regulation of the synthesis of specific uptake systems for toluenesulphonate (Locher et al., 1993) and terephthalate (this work), and of a putative transport system for sulphobenzoate, is as yet undefined. Enzyme abbreviations are defined on the title page; substrates are abbreviated as follows: COL, 4carboxybenzyl alcohol; CYD, 4-carboxybenzaldehyde; DCD, (1R,2S)-dihydroxy-1,4-dicarboxy-3,5-cyclohexadiene; PC, protocatechuate; PSB, 4-sulphobenzoate; SOL, 4-sulphobenzyl alcohol; SYD, 4-sulphobenzaldehyde; TC, 4toluenecarboxylate; TER, terephthalate; TS, 4-toluenesulphonate.

dizes sulphobenzyl alcohol and carboxybenzyl alcohol to the corresponding aldehydes, 4-sulphobenzaldehyde and 4-carboxybenzaldehyde, respectively. The aldehydes are oxidized by 4-sulphobenzaldehyde dehydrogenase, SYDDH, to 4-sulphobenzoate and terephthalate (Locher et al., 1989, 1991c). Sulphobenzoate is the substrate for the two-component 4-sulphobenzoate 3,4-dioxygenase system, PSBDOS, which yields protocatechuate (Locher et al., 1991a). PSBDOS consists of a homomultimeric oxygenase (component A) presumably coupled to the uncharacterized reductase $C$; the system, however, is active and was characterized with the reductase of TSMOS (component B) (Locher et al., 1991a, b). Protocatechuate is further metabolized via the 4,5 meta-cleavage pathway (Locher et al., 1989). Terephthalate is oxygenated to the diene-diol $(1 \mathrm{R}, 2 S)$-dihydroxy-1,4-dicarboxy-3,5cyclohexadiene by the multicomponent terephthalate 1,2dioxygenase system, TERDOS, which consists of a heteromultimeric oxygenase (component $\mathrm{Z}$ ) and partially characterized reductase component(s) (Schläfli et al., 1994). The diene-diol is oxidized to protocatechuate by a $(1 R, 2 S)$-dihydroxy-1,4-dicarboxy-3,5-cyclohexadiene dehydrogenase, DCDDH (Saller et al., 1995).
We now report on the patterns of induction of components of the pathways degrading toluenesulphonate and toluate in C. testosteroni $\mathrm{T}-2$.

\section{METHODS}

Materials. 4-Sulphobenzoate was from Aldrich. The sources of other chemicals, and of materials for protein purification and characterization, and for immunological experiments, are given elsewhere (Locher et al., 1989; Schläfli et al., 1994; Thurnheer $e t$ al., 1986).

Growth of the organism and preparation of cell-free extracts. C. testosteroni strain T-2 (DSM 6577) was grown in batch culture (portions of 11 in 51 flasks) in mineral salts medium containing $6 \mathrm{mM}$ (aromatic substrate) or $10 \mathrm{mM}$ (succinate) carbon source, essentially as described previously (Locher et al., 1989; Thurnheer et al., 1986); the medium was adjusted to $\mathrm{pH} 7 \cdot 2$ for sulphonated aromatics, to $\mathrm{pH} \mathrm{6.8}$ for terephthalate, and to $\mathrm{pH} 7 \cdot 0$ for other substrates. For experiments with whole cells, portions of $20 \mathrm{ml}$ were taken at intervals from the cultures. Reproducible activities could be measured when the cells were immediately chilled in an ice-water slurry and centrifuged at $4{ }^{\circ} \mathrm{C}$ for $20 \mathrm{~min}$ at $5000 \mathrm{~g}$. The cells were washed, suspended in $0 \cdot 5-1 \mathrm{ml} 20 \mathrm{mM}$ phosphate buffer, $\mathrm{pH} 7 \cdot 0$ (buffer A), and stored on ice. Oxygen uptake rates remained stable for at least $5 \mathrm{~h}$. Cells 
for the preparation of extracts were harvested in the late exponential growth phase (approx. $200 \mathrm{mg}$ protein $\mathrm{l}^{-1}$ ) and stored frozen as described previously (Locher et al., 1991a). Cells were disrupted in a French pressure cell, and crude extract, in buffer A containing $1 \mathrm{mM}$ dithiothreitol, was prepared as detailed elsewhere (Locher et al., 1991a).

Analytical methods. The concentrations of aromatic compounds were determined by HPLC on reversed-phase columns (Thurnheer et al., 1986); UV spectra were recorded in a diode array detector. Protein concentration in cell extracts was measured by the method of Bradford (1976) with bovine serum albumin as standard. The protein content of cell suspensions was assayed by a Lowry method (Kennedy \& Fewson, 1968) with bovine serum albumin as standard. SDS-PAGE (Laemmli, 1970) was used to monitor the protein patterns of crude extracts and to separate oxygenase components for the affinity purification of antibodies (see below). Proteins in gels were visualized with Coomassie brilliant blue (Laemmli, 1970; Locher et al., 1991a). Low-range prestained SDS-PAGE molecular mass standards were used (Bio-Rad), consisting of phosphorylase $b(106 \mathrm{kDa})$, bovine serum albumin $(80 \mathrm{kDa})$, ovalbumin (49.5 kDa), carbonic anhydrase $(32.5 \mathrm{kDa})$, soybean trypsin inhibitor $(27.5 \mathrm{kDa})$ and lysozyme (18.5 kDa). Immunological detection of oxygenase components in separated proteins was done after proteins were blotted from SDS-PAGE onto nitrocellulose membranes. Blotting was at $4{ }^{\circ} \mathrm{C}$ in a Mini TransBlot cell (Bio-Rad) at $100 \mathrm{~V}(250 \mathrm{~mA})$ for 1 h or at $30 \mathrm{~V}(40 \mathrm{~mA})$ overnight, as detailed elsewhere (Schläfli et al., 1994).

Enzyme assays. Oxygen uptake rates of resting cells (pathway activities; see Results for explanation) were measured at $30^{\circ} \mathrm{C}$ in a Clark-type oxygen electrode with a $1 \mathrm{ml}$ reaction vessel. Washed cell suspension $(10-50 \mu \mathrm{l})$ was added to $0.5 \mathrm{ml}$ of buffer A, equilibrated for $2 \mathrm{~min}$, and the reaction was started by the addition of $600 \mathrm{nmol}$ substrate. TSMOS was assayed as 4ethylbenzoate-dependent oxygen uptake (Locher $e t$ al., 1991b). TERDOS was assayed as pyridine-2,5-dicarboxylate-dependent oxygen uptake (Schläfli et al., 1994). The activity of PSBDOS was calculated from oxygen uptake rates with sulphobenzoate, corrected for the presence of protocatechuate 4,5-dioxygenase (PC45O) (Locher et al., 1991a). Unless otherwise indicated, all oxygenase assays contained (in $0.5 \mathrm{ml}$ ) $1 \mathrm{mg}$ protein and activities were not optimized for the concentration of enzyme components (see Results for explanation). SOLDH was measured spectrophotometrically as the back reaction, i.e. the carboxybenzaldehyde-dependent oxidation of NADH (Locher et al., 1991c). DCDDH was measured spectrophotometrically as diene-diol-dependent generation of NADH (Schläfli et al., 1994). Dehydrogenase assays contained $50-500 \mu \mathrm{g}$ protein. Components of oxygenases were purified as described elsewhere (Locher et al., 1991a, b; Schläfli et al., 1994).

Production and purification of specific antisera. All animal experiments were done accoruing to the guidelines of the Schweizer Bundesamt für Veterinärwesen and approved by the Kantonale Aufsichtskommission für Tierversuche. Polyclonal antisera were raised in female New Zealand White rabbits against oxygenase $M$ and reductase $B$ of TSMOS, oxygenase A of PSBDOS and oxygenase Z of TERDOS (Schläfli et al., 1994). Useful dilutions for the crude antisera were 1:100 for anti-B, $1: 1000$ for anti-M and anti- $Z$, respectively, and more than $1: 10000$ for anti-A. The crude antisera were purified by preincubation with the appropriate antigens separated by SDSPAGE and blotted on to nitrocellulose membranes (Harlow \& Lane, 1988). The purified antisera were used at dilutions of 1:25 (1:50 for anti-A). All affinity-purified antisera were highly specific: there was essentially no reaction (under standard conditions) of any of the three antisera raised against an oxygenase component (anti- $\mathrm{A}$, anti-M or anti- $\mathrm{Z} \alpha$ ) with any of the other two oxygenase components. Antiserum specific for component (reductase B) of TSMOS did not react with any other protein in any extract of $C$. testosteroni $\mathrm{T}-2$ tested.

\section{RESULTS}

\section{Growth kinetics}

C. testosteroni T-2 grows exponentially in toluenesulphonate-salts medium $\left(\mu=0.37 \mathrm{~h}^{-1}\right)$, and the more rapid growth with toluenesulphonate than with sulphobenzoate has been interpreted as the explanation for transient excretion of sulphobenzoate in toluenesulphonate-salts medium (Table 1). No other excreted intermediate is detected, and growth is directly proportional to the total aromatic substrate utilized (Locher et al., 1989). C. testosteroni T-2 grows in sulphobenzyl alcohol-salts and in sulphobenzaldehyde-salts medium, but no growth kinetics could be examined due to the scarcity of these compounds (C. Malli \& A. M. Cook, unpublished). Sulphobenzoate is utilized without detectable excretion of intermediates (Locher et al., 1989). C. testosteroni T-2 grew in toluate-salts medium with the lowest growth rate of any compound tested (Table 1). Nonetheless, considerable transient accumulation of carboxybenzyl alcohol and terephthalate was observed. When the organism was grown in carboxybenzyl alcoholsalts medium, terephthalate was excreted transiently (Table 1). C. testosteroni T-2 in carboxybenzaldehyde-salts medium excreted carboxybenzyl alcohol and terephthalate transiently (Fig. 2). In contrast, terephthalate was utilized without detectable excretion of intermediates. In all cases there was mass balance, the growth yield being about $5 \mathrm{~g}$ protein per mol C (cf. Cook, 1987).

\section{Enzyme assays}

The specific activity of a multicomponent oxygenase is usually difficult to measure in cell extracts (e.g. Bünz \& Cook, 1993; Locher et al., 1991a; Tan et al., 1994; Thurnheer et al., 1990), a problem that might be avoided by measuring the activities in whole cells (Tan et al., 1994). In our case, however, the substrate-dependent oxygen uptake rate of cells represents not only the activity of the specific oxygenative enzyme but also the transport of the substrate into the cell (Locher et al., 1993), and, in the case of toluenesulphonate (and TSMOS) for example, two additional oxygenases (PSBDOS, PC45O) which oxygenate pathway intermediates (Locher et al., 1989), and possibly also respiration. We were unable to eliminate these problems by using substrate analogues [4-ethylbenzoate for TSMOS and pyridine-2,5-dicarboxylate for TERDOS (Locher et al., 1991b; Schläfli et al., 1994)], because neither compound was biotransformed by appropriately induced whole cells, presumably because of a permeability barrier. Oxygen uptake rates of washed cells were thus regarded in this work as pathway activities, and not as oxygenase activities.

For reasons which should become clear in the following 


\section{Table 1. Some growth characteristics of $C$. testosteroni T-2}

The data are representative of three or more batch cultures with, initially, $6 \mathrm{mM}$ substrate $(10 \mathrm{mM}$ for succinate). Substantial lag phases $(14-20 \mathrm{~h}$ ) were observed routinely when toluate-salts medium was inoculated from actively growing precultures in toluate-salts medium; other media supported almost immediate growth after homologous transfer.

\begin{tabular}{|lcccc|}
\hline Substrate & $\begin{array}{c}\text { Growth rate } \\
\left(\boldsymbol{\mu}, \mathbf{h}^{-\mathbf{1}}\right)\end{array}$ & \multicolumn{3}{c|}{ Metabolites detected during growth (mM)* } \\
\cline { 3 - 5 } & & $\begin{array}{c}\text { Carboxybenzyl } \\
\text { alcohol }\end{array}$ & Terephthalate & Sulphobenzoate \\
\hline Toluenesulphonatef & 0.37 & ND & ND & 1.5 \\
Sulphobenzoate† & 0.30 & ND & ND & ND \\
Toluate & 0.20 & 1.9 & 2.0 & ND \\
Carboxybenzyl alcohol & 0.50 & - & 0.5 & ND \\
Carboxybenzaldehyde & 0.24 & $1 \cdot 1$ & 3.4 & ND \\
Terephthalate & 0.37 & ND & ND & ND \\
Succinate & 0.77 & ND & ND & ND \\
\hline
\end{tabular}

ND, Not detected.

* Maximal concentration of excreted intermediate during growth.

† Published data (Locher et al., 1989).

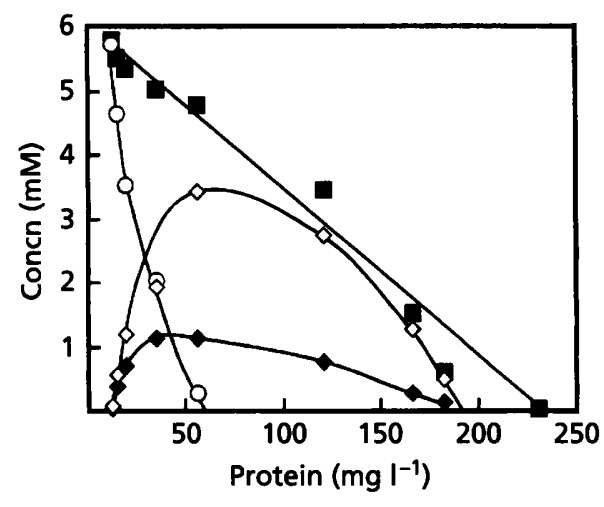

Fig. 2. Growth of C. testosteroni $T-2$ in $6 \mathrm{mM}$ carboxybenzaldehyde-salts medium as a differential plot of substrate utilization as a function of growth. $\square$, Sum of the concentrations of substrate and excreted metabolites; ๑, carboxybenzyl alcohol; $O$, carboxybenzaldehyde; $\diamond$, terephthalate.

Results, we chose not to measure activities of each multicomponent oxygenase in cell extracts in a linearized assay (cf. Tan et al., 1994), but to use the older method of doing all assays at the arbitrarily set protein concentration of $2 \mathrm{mg} \mathrm{m}^{-1}$ (Geary et al., 1990). The data obtained may therefore not represent in vivo conditions but they allow, together with the immunoblots, an unambiguous characterization of the different extracts.

SOLDH, PC45O and DCDDH, whose assays present no problem (Locher et al., 1991c; Schläfli et al., 1994), were measured in appropriately diluted crude extracts. SYDDH was assayed but not quantified, because it was unstable in cell extracts.

\section{Pathway activities, enzyme activities and their induction}

The pathway activities for e.g. toluenesulphonate degradation and sulphobenzoate degradation in toluenesulphonate cultures and for terephthalate degradation in terephthalate cultures were essentially stable throughout growth and decreased only slowly in the stationary phase (not shown). Typical values for pathway activities are given in Table 2 . The half-life of pathway activities in the stationary phase was about $50 \mathrm{~h}$ (not shown).

Oxygen uptake with protocatechuate was detected in all cells grown with aromatic compounds (Table 2). The inducible nature of these pathways was supported by the absence of activities in succinate-grown cells, and was largely confirmed (see below), when enzyme activities were measured.

One of the highest pathway specific activities observed was for toluenesulphonate in toluenesulphonate-grown cells (Table 2). The specific activity for sulphobenzoate in these cells was much lower, which we presume to cause a build-up of that compound in the cell followed by the excretion of sulphobenzoate in toluenesulphonate cultures (Tables 1 and 2). Activity for toluate and terephthalate was also observed (Table 2). The pathway specific activity for sulphobenzoate in sulphobenzoategrown cells was lower than that in toluenesulphonategrown cells; the ratio of specific activities toluenesulphonate: sulphobenzoate was similar to that in toluenesulphonate-grown cells. Minimal activity with toluate but none with terephthalate was observed in these cells (Table 2).

The highest pathway specific activity was for toluate in toluate-grown cells (Table 2), with the specific activity for terephthalate lower; we presume this to cause a build-up 
Table 2. Oxygen uptake rates of whole cells with different pathway intermediates as assays of the pathway activities in cells of $C$. testosteroni T-2 grown with different substrates

The data are representative of cells from three growth experiments.

\begin{tabular}{|c|c|c|c|c|c|}
\hline \multirow[t]{2}{*}{ Growth substrate } & \multicolumn{5}{|c|}{$\begin{array}{l}\text { Oxygen uptake rates [mkat (kg protein) }{ }^{-1} \text { ] of washed cells } \\
\text { to which were added }\end{array}$} \\
\hline & $\begin{array}{l}\text { Toluene- } \\
\text { sulphonate }\end{array}$ & $\begin{array}{l}\text { Sulpho- } \\
\text { benzoate }\end{array}$ & Toluate & Terephthalate & $\begin{array}{l}\text { Proto- } \\
\text { catechuate }\end{array}$ \\
\hline Toluenesulphonate & $7 \cdot 1$ & $3 \cdot 4$ & $4 \cdot 5$ & $1 \cdot 1$ & $5 \cdot 0$ \\
\hline Sulphobenzoate & $4 \cdot 2$ & $2 \cdot 3$ & $1 \cdot 0$ & $<0.1$ & $3 \cdot 7$ \\
\hline Toluate & $1 \cdot 6$ & $<0.1$ & $8 \cdot 6$ & $5 \cdot 3$ & $3 \cdot 5$ \\
\hline Terephthalate & $<0 \cdot 1$ & 0.4 & $<0.1$ & $4 \cdot 4$ & $4 \cdot 0$ \\
\hline Protocatechuate & $<0.1$ & $<0.1$ & $<0 \cdot 1$ & $<0.1$ & $5 \cdot 1$ \\
\hline Succinate & $<0.1$ & $<0.1$ & $<0.1$ & $<0.1$ & $<0.1$ \\
\hline
\end{tabular}

Table 3. Induction of enzymes in C. testosteroni T-2

The data are representative of three or more independent measurements.

\begin{tabular}{|lccccc|}
\hline Growth substrate & \multicolumn{5}{c|}{$\begin{array}{c}\text { Enzyme (system) activities [mkat (kg protein) } \\
\text { in crude extracts of C. } \text { testosteroni }^{-1} \text { T-2 }\end{array}$} \\
\cline { 2 - 5 } & TSMOS & SOLDH & PSBDOS & TERDOS & DCDDH \\
\hline Toluenesulphonate & 4.0 & 152 & 0.4 & 0.1 & 3.5 \\
Sulphobenzoate & 0.5 & 45.2 & 0.2 & ND & 1.8 \\
Toluate & 1.5 & 94 & ND & 0.35 & 13 \\
Terephthalate & ND & 5.6 & ND & 0.54 & $9 \cdot 9$ \\
Succinate & ND & 0.8 & ND & ND & ND \\
\hline
\end{tabular}

ND, Not detected. Oxygen uptake rates of up to $0.05 \mathrm{mkat}(\mathrm{kg} \text { protein })^{-1}$ were observed in these extracts, but HPLC revealed no transformation of substrate.

of terephthalate in the cell followed by the excretion of that compound during growth in toluate-salts medium (Table 1, Fig. 2), though the pathway activities do not correspond to the growth rates (Table 1). The toluategrown cells failed to oxygenate sulphobenzoate and had a low activity with toluenesulphonate. The terephthalategrown cells had a pathway activity effectively only with terephthalate; there was no activity for toluate or toluenesulphonate, and a minimal activity with sulphobenzoate (Table 2).

No activity of TSMOS, PSBDOS, TERDOS or DCDDH (Table 3) was found in extracts of succinate-grown cells, and only traces of SOLDH (Table 3) and PC45O (Locher et al., 1989) were detected. All activities thus appeared to be inducible.

Toluenesulphonate and toluate both induced TSMOS and SOLDH at very high levels, though activities in extracts of toluenesulphonate-grown cells were two- to threefold higher. Significant but lower levels of TSMOS and SOLDH were also observed in extracts from sulphobenzoate-grown cells, whereas very low activities of
SOLDH only were found in extracts of terephthalategrown cells. The ratio of activities TSMOS:SOLDH was constant at about 1:60 in active extracts. SYDDH was detected only in those extracts containing significant levels of TSMOS and SOLDH. Extracts of cells grown in carboxybenzaldehyde contained active TSMOS and SOLDH (not shown). It would appear that the enzymes TSMOS, SOLDH and SYDDH share one pattern of induction.

Extracts of toluenesulphonate-grown cells contained the highest level of measurable PSBDOS activity [0.4 mkat (kg protein $)^{-1}$; Table 3]. The activity in extracts of sulphobenzoate-grown cells was only $0.2 \mathrm{mkat}(\mathrm{kg}$ protein $)^{-1}$, whereas extracts of toluate- and terephthalategrown cells were inactive. The level of activity was independent of that of TSMOS $(1: 2 \cdot 5,1: 10$ and $<1: 25$ in extracts of sulphobenzoate-, toluenesulphonate- and toluate-grown cells, respectively; Table 3) and of that of TERDOS (4:1 and $<1: 18$ in extracts of toluenesulphonate- and terephthalate-grown cells, respectively). PSBDOS is thus regulated independently of both TSMOS and of TERDOS. 


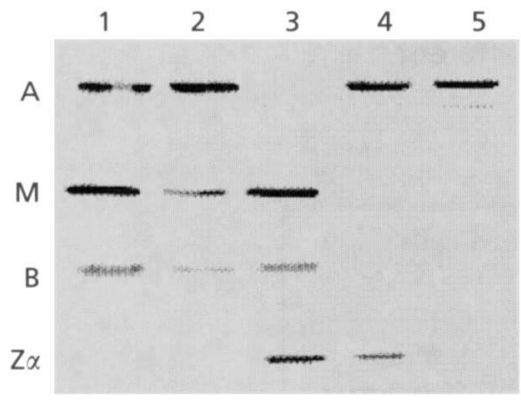

Fig. 3. Composite Western blots on nitrocellulose of extracts from C. testosteroni T-2 grown with different carbon sources and separated by SDS-PAGE. The same amount of protein $(5 \mu \mathrm{g})$ was separated in each lane. Extracts were from cells grown with toluenesulphonate (lane 1), sulphobenzoate (lane 2), toluate (lane 3), terephthalate (lane 4) and succinate (lane 5). The blotted extracts were incubated with antisera specific for oxygenase $A$ from PSBDOS (row A), oxygenase $M$ from TSMOS (row M), reductase B from TSMOS (row B), and the $\alpha$-subunit of oxygenase $Z$ from TERDOS (row $Z \alpha$ ). The image is a digitized composite; only those parts of the immunoblots which showed a significant reaction with the antisera are represented.

The most active TERDOS was found in extracts of terephthalate-grown cells, with somewhat lower levels in those of toluate-grown cells (Table 3 ). Activity could also be detected in extracts of toluenesulphonate-grown cells, corresponding to weak activity detected previously (Locher et al., 1991c), with traces in extracts of sulphobenzoate-grown cells too (no transformation of substrate). The ratio of the activities of TERDOS:DCDDH in all active extracts was about $1: 25$. We thus consider TERDOS and DCDDH to belong to a further regulatory unit.

\section{Expression of oxygenase components}

Extracts of cells grown with the five standard carbon sources were separated by SDS-PAGE. Four different patterns were observed (not shown), with extracts of toluenesulphonate- and sulphobenzoate-grown cells sharing a pattern. The expression of oxygenase components $\mathrm{B}, \mathrm{M}, \mathrm{A}$ and $\mathrm{Z}$ was investigated using specific antisera (Fig. 3). Immunodetection of proteins in blotted extracts confirmed that components $B$ (reductase) and $M$ (oxygenase) of TSMOS were present only in extracts of toluenesulphonate-, toluate- and sulphobenzoate-grown cells. Signals with anti- $Z \alpha$ (the large oxygenase subunit of TERDOS) (and with anti-Z $\beta$, not shown) were readily visible in extracts of toluate- and terephthalate-grown cells, whereas the extract of toluenesulphonate-grown cells gave a weak signal (invisible in Fig. 3 ) and the extract of sulphobenzoate-grown cells none. Oxygenase $A$, in contrast, was detected in all samples, except the extract of toluate-grown cells. Thus even the extract of succinategrown cells contained immunologically detectable amounts of oxygenase A, though no activity was found under the standard conditions (Tables 2 and 3). The presence of oxygenase A in protocatechuate-grown cells was not examined.
When extracts of terephthalate-grown or succinate-grown cells were incubated with added reductase $B$, PSBDOS activity was detected. The oxygenase component $A$, and not some cross-reacting protein, is thus present in succinate-grown and in terephthalate-grown cells.

\section{DISCUSSION}

\section{Stability of multicomponent oxygenases}

The loss of activity of multicomponent oxygenases in the stationary phase is considered normal, whether observed directly (Bünz \& Cook, 1993; Junker et al., 1994a, b; Moodie et al., 1990; Sauber et al., 1977; Thurnheer et al., 1986; Wackett, 1990) or deduced from a comment on the correct timing for harvesting cells to purify proteins (Ensley et al., 1982; Geary et al., 1990; Pilkington \& Dalton, 1990; Tonge et al., 1977; Yamaguchi \& Fujisawa, 1978). Our laboratory's initial experience with $C$. testosteroni T-2 seemed to be similar (Locher et al., 1991a). After optimizing the growth conditions and refining the assay procedure for whole cells, we were surprised to find constant pathway activities throughout exponential growth (cf. Bünz \& Cook, 1993; Junker et al., 1994b) and high stability of these activities after growth (cf. Bünz \& Cook, 1993; Junker et al., 1994b; Moodie et al., 1990). This behaviour of $C$. testosteroni $\mathrm{T}-2$ is not only unusual, but it appears to be both metabolically expensive, given the large amounts of protein involved (often $4-10 \%$ of soluble protein per oxygenase component) (Locher $\mathrm{et} \mathrm{al.,}$ 1991a, b; Schläfli et al., 1994) and potentially harmful, in that the combination of reductase and oxygenase will tend to yield active oxygen species which may damage the cell. In this latter argument, a degradation of the reductase at least (Moodie et al., 1990) would reduce this risk. We do not know how $C$. testosteroni $\mathrm{T}-2$ maintains these activities. The generally short half-life of bacterial mRNA implies that the enzymes themselves are very stable in the cell. It would be interesting to see whether oxygenase systems in general are stable in this organism, or whether the effect is limited to TSMOS, TERDOS and PSBDOS.

\section{Convergent and divergent pathways}

Reviews of the degradation of aromatic compounds stress the convergence of pathways to yield the relatively few compounds subject to ring cleavage (cf. Dagley, 1975; Fewson, 1981; Stanier \& Ornston, 1973), typified by the convergence of the metabolism of sulphobenzoate and terephthalate at protocatechuate, with subsequent ring cleavage of protocatechuate (Fig. 1). In C. testosteroni T-2, however, we also observe the less usual divergence of metabolism, caused by compounds sharing a common pathway and then requiring different reactions to allow entry to the common meta pathway (Fig. 1). The enzymes involved in the divergence are obviously required in large amounts in the cell, representing several percent of the cellular soluble protein (Locher et al., 1991a; Schläfli et al., 1994). Presumably for reasons of economy with protein synthesis, the organism regulates the degradative pathway in separate units, which we term regulatory unit R1 for 
sidechain manipulation, regulatory unit R2 for removal of a carboxy substituent and preparation for ring cleavage, regulatory unit $\mathrm{R} 3$ for removal of a sulphono substituent and preparation for ring cleavage, and regulatory unit R4 comprising ring cleavage and possibly further reactions of the meta pathway (Fig. 1).

\section{Regulatory unit R1}

We consider this regulatory unit to consist of three catalytic activities, TSMOS (components $B$ and $M$ ), SOLDH and SYDDH. These three enzymes were always synthesized (or absent) as a group (Table 3, Fig. 3). Where measurable, there was a constant ratio of specific activities (TSMOS: SOLDH; Table 3), and the presence of TSMOS and SOLDH during growth in carboxybenzaldehydesalts medium confirmed the joint regulation. We do not yet know whether the transport of toluenesulphonate (Locher et al., 1993) into the cell is co-regulated with the metabolic enzymes or what role transport, whose presence is deduced from the putative permeability barrier to ethylbenzoate, plays in the metabolism of toluate (cf. Harwood et al., 1994).

Oxidation of the methyl sidechain of an aromatic compound results from a common set of degradative reactions (Assinder \& Williams, 1990; Gibson \& Subramanian, 1984; Locher et al., 1991c; Mahajan et al., 1994; Whited \& Gibson, 1991), though the similarity of the chemistry need not indicate similarity of the enzymes (Locher $e t$ al., 1991c). The regulation of the sidechain-oxidizing enzymes of TOL plasmid pWW0 is well characterized at the molecular level. The structural genes for the monooxygenase oxygenase $(x y l M)$ and reductase components $(x y l A)$, the alcohol dehydrogenase $(x y / B)$ and the aldehyde dehydrogenase $(x y / C)$, together with a gene of unknown function $(x y l N)$, are clustered in one operon $(x y l C M A B N)$ (Harayama et al., 1986). As with $C$. testosteroni $\mathrm{T}-2$, the three enzyme activities are coregulated. Transcription of the operon from the $\sigma^{54}$ promoter $P u$ is regulated by the positive regulator XylR, which is activated by the presence of upper-pathway substrates/intermediates (Assinder \& Williams, 1990). In contrast to the situation in $C$. testosteroni $\mathrm{T}-2$, strong transcription from $P u$ only occurs in the late exponential growth phase (Hugouvieux-Cotte-Pattat et al., 1990; Lorenzo et al., 1993). Nothing is known about the stability of the enzymes in the stationary growth phase or the regulatory proteins which control the growth-phasedependent regulation.

\section{Regulatory unit R2}

We consider this regulatory unit to consist of two enzymes, TERDOS and DCDDH. These two enzymes were always expressed (or absent) as a group with comparable ratios of activity, where both enzymes could be quantified (Table 3). The known structural genes of ring-activating multicomponent non-haem iron dioxygenase systems and the corresponding diene-diol dehydrogenases are clustered (Bergeron et al., 1994;
Denome et al., 1993; Harayama et al., 1991; Hofer et al., 1993; Neidle et al., 1987; Tan \& Fong, 1993; Zylstra \& Gibson, 1989) and co-regulation of the two enzymes appears to be common. We anticipate a similar arrangement for TERDOS and DCDDH in C. testosteroni T-2.

We found evidence, in the form of an apparent permeability barrier to a substrate analogue, for the specific uptake of terephthalate by $C$. testosteroni $\mathrm{T}-2$. The nature of the transport system and the regulation of its expression remain unclear.

\section{Regulatory unit R3}

This regulatory unit is presumed to consist of at least the oxygenase (component A) of PSBDOS. This dioxygenase system was initially described as a two-component system, consisting of the components A (oxygenase) and B (reductase); a reductase $C$ was observed but not characterized (Locher et al., 1991a). Our results confirm the subsequent suggestion of Locher et al. (1991b), that the expression of reductase $\mathrm{B}$ is controlled by regulatory unit R1 as a component of TSMOS. However, we found no evidence for reductase $C$; in contrast, under growth conditions where PSBDOS activity was needed, regulatory unit R1 was expressed, presumably to complement oxygenase A of PSBDOS with reductase B from TSMOS in vivo. It is unusual that two components of an oxygenase are in different regulatory units (van der Meer et al., 1992), and the observation of two reductases for the dibenzofuran dioxygenase system (Bünz \& Cook, 1993) was attributed to two constitutive pathways. It will be interesting to explore whether PSBDOS is a new acquisition in strain $\mathrm{T}-2$, whether a mutation since isolation of the organism has led to loss of reductase $C$, whether reductase $B$ is a better reductive unit for PSBDOS than reductase $\mathrm{C}$, or whether some other explanation is required.

A fourth regulatory unit (Table 2, Fig. 1) is presumed to comprise the ring-cleaving enzyme, PC45O, and possibly the whole of the meta cleavage pathway of $C$. testosteroni T-2 (cf. Assinder \& Williams, 1990; Doten et al., 1987).

\section{ACKNOWLEDGEMENTS}

H.R.S.O. was supported by a grant from the Swiss Federal Institute of Technology, Zürich. We are grateful to Dr Hans $\mathrm{H}$. Locher, Hoffmann-LaRoche, Basel, for helpful discussions and for supplying oxygenase components.

\section{REFERENCES}

Assinder, S. J. \& Williams, P. A. (1990). The TOL plasmids: determinants of the catabolism of toluene and the xylenes. $A d v$ Microb Pbysiol 31, 1-69.

Bergeron, J., Ahmad, D., Barriault, D., Larose, A., Sylvestre, M. \& Powlowski, J. (1994). Identification and mapping of the gene translation products involved in the first steps of the Comamonas testosteroni b-356 biphenyl chlorobiphenyl biodegradation pathway. Can J Microbiol 40, 743-753.

Bradford, M. (1976). A rapid and sensitive method for the 
quantitation of microgram quantities of protein utilizing the principle of protein-dye binding. Anal Biocbem 72, 248-254.

Bunz, P. \& Cook, A. M. (1993). Dibenzofuran 4,4a-dioxygenase from Sphingomonas sp. strain RW1: angular dioxygenation by a three-component enzyme system. J Bacteriol 175, 6467-6475.

Cook, A. M. (1987). Biodegradation of s-triazine xenobiotics. FEMS Microbiol Rev 46, 93-116.

Dagley, S. (1975). A biochemical approach to some problems of environmental pollution. Essays Biochem 11, 81-138.

Denome, S. A., Stanley, D. C., Olson, E. S. \& Young, K. D. (1993). Metabolism of dibenzothiophene and naphthalene in Pseudomonas strains: complete DNA sequence of an upper naphthalene catabolic pathway. J Bacteriol 175, 6890-6901.

Doten, R. C., Ngai, K.-L., Mitchell, D. J. \& Ornston, L. N. (1987). Cloning and genetic organization of the pca gene cluster from Acinetobacter calcoaceticus. J Bacteriol 169, 3168-3174.

Ensley, B. D., Gibson, D. T. \& Laborde, A. L. (1982). Oxidation of naphthalene by a multicomponent enzyme system from Pseudomonas sp. strain NCIB 9816. J Bacteriol 149, 948-954.

Fewson, C. A. (1981). Biodegradation of aromatics with industrial relevance. In Microbial Degradation of Xenobiotics and Recalcitrant Compounds, pp. 141-179. Edited by T. Leisinger, A. M. Cook, R. Hütter \& J. Nüesch. London: Academic Press.

Geary, P. J., Mason, J. R. \& Joannou, C. L. (1990). Benzene dioxygenase from Pseudomonas putida ML2 (NCIB 12190). Methods Envymol 188, 52-60.

Gibson, D. T. \& Subramanian, V. (1984). Microbial degradation of aromatic hydrocarbons. In Microbial Degradation of Organic Compounds, pp. 181-252. Edited by D. T. Gibson. New York: Marcel Dekker.

Harayama, S., Leppik, R. A., Rekik, M., Mermod, N., Lehrbach, P. R., Reineke, W. \& Timmis, K. N. (1986). Gene order of the TOL catabolic plasmid upper pathway operon and oxidation of both toluene and benzyl alcohol by the $x y l A$ product. $J$ Bacteriol 167, 455-461.

Harayama, S., Rekik, M., Bairoch, A., Neidle, E. L. \& Ornston, L. N. (1991). Potential DNA slippage structures acquired during evolutionary divergence of Acinetobacter calcoaceticus chromosomal ben $A B C$ and Pseudomonas putida TOL pWW0 plasmid $x y / X Y Z$ genes encoding benzoate dioxygenases. $J$ Bacteriol 173, 7540-7548.

Harlow, E. \& Lane, D. (1988). Antibodies: a Laboratory Manual. Cold Spring Harbor, NY: Cold Spring Harbor Laboratory.

Harwood, C. S., Nichols, N. N., Kim, M. K., Ditty, J. L. \& Parales, R. E. (1994). Identification of the pcaRKF gene cluster from $P_{\text {seudo- }}$ monas putida: involvement in chemotaxis, biodegradation, and transport of 4-hydroxybenzoate. J Bacteriol 176, 6479-6488.

Hofer, B., Eltis, L. D., Dowling, D. N. \& Timmis, K. N. (1993). Genetic analysis of a Pseudomonas locus encoding a pathway for biphenyl/polychlorinated biphenyl degradation. Gene 130, 47-55.

Hugouvieux-Cotte-Pattat, N., Köhler, T., Rekik, M. \& Harayama, S. (1990). Growth-phase-dependent expression of the Pseudomonas putida TOL plasmid $\mathrm{pWW} 0$ catabolic genes. $J$ Bacteriol 172, 6651-6660.

Junker, F., Field, J. A., Bangerter, F., Ramsteiner, K., Kohler, H.-P., Joannou, C. L., Mason, J. R., Leisinger, T. \& Cook, A. M. (1994a). Dioxygenation and spontaneous deamination of 2-aminobenzenesulphonic acid in Alcaligenes sp. strain O-1 with subsequent meta ring cleavage and spontaneous desulphonation to 2-hydroxymuconic acid. Biocbem J 300, 429-436.

Junker, F., Leisinger, T. \& Cook, A. M. (1994b). 3-Sulphocatechol 2,3-dioxygenase and other dioxygenases (EC 1.13.11.2 and EC 1.14.12. -) in the degradative pathways of 2-aminobenzene- sulphonic, benzenesulphonic and 4-toluenesulphonic acids in Alcaligenes sp. strain O-1. Microbiology 140, 1713-1722.

Kennedy, S. I. T. \& Fewson, C. A. (1968). Enzymes of the mandelate pathway in bacterium N. C. I. B. 8250. Biochem J 107, 497-506.

Laemmli, U. K. (1970). Cleavage of structural proteins during the assembly of the head of bacteriophage T4. Nature 227, 680-685.

Locher, H. H., Leisinger, T. \& Cook, A. M. (1989). Degradation of $p$-toluenesulphonic acid via sidechain oxidation, desulphonation and meta ring cleavage in Pseudomonas (Comamonas) testosteroni $\mathrm{T}-2$. $J$ Gen Microbiol 135, 1969-1978.

Locher, H. H., Leisinger, T. \& Cook, A. M. (1991a). 4-Sulphobenzoate 3,4-dioxygenase: purification and properties of a desulphonative two-component enzyme system from Comamonas testosteroni T-2. Biochem J 274, 833-842.

Locher, H. H., Leisinger, T. \& Cook, A. M. (1991b). 4-Toluene sulfonate methyl-monooxygenase from Comamonas testosteroni $\mathrm{T}-2$ : purification and some properties of the oxygenase component. J Bacteriol 173, 3741-3748.

Locher, H. H., Malli, C., Hooper, S., Vorherr, T., Leisinger, T. \& Cook, A. M. (1991c). Degradation of $p$-toluic acid ( $p$-toluene carboxylic acid) and $p$-toluene sulphonic acid via oxygenation of the methyl sidechain is initiated by the same set of enzymes in Comamonas testosteroni T-2. J Gen Microbiol 137, 2201-2208.

Locher, H. H., Poolman, B., Cook, A. M. \& Konings, W. N. (1993). Uptake of 4-toluenesulfonate by Comamonas testosteroni T-2. J Bacteriol 175, 1075-1080.

Lorenzo, D. V., Cases, I., Herrero, M. \& Timmis, K. N. (1993). Early and late responses of TOL promoters to pathway inducers: identification of postexponential promoters in Pseudomonas putida with lacZ-tet bicistronic reporters. J Bacteriol 175, 6902-6907.

Mahajan, M. C., Phale, P. S. \& Vaidyanathan, C. S. (1994). Evidence for the involvement of multiple pathways in the biodegradation of 1- and 2-methylnaphthalene by Pseudomonas putida CSVS6. Arch Microbiol 161, 425-433.

van der Meer, J. R., de Vos, W. M., Harayama, S. \& Zehnder, A. J. B. (1992). Molecular mechanisms of genetic adaption to xenobiotic compounds. Microbiol Rev 56, 677-694.

Moodie, F. D. L., Woodland, M. P. \& Mason, J. R. (1990). The reductase component of the chromosomally encoded benzoate dioxygenase from Pseudomonas putida C-1 is immunologically homologous with a product of the plasmid encoded $x y l D$ gene (toluate dioxygenase) from Pseudomonas putida mt-2. FEMS Microbiol Lett 71, 163-168.

Neidle, E., Shapiro, M. K. \& Ornston, L. N. (1987). Cloning and expression in Escherichia coli of Acinetobacter calcoaceticus genes for benzoate degradation. J Bacteriol 169, 5496-5503.

Pilkington, S. J. \& Dalton, H. (1990). Soluble methane monooxygenase from Methylococcus capsulatus Bath. Methods Enzymol 188, 181-190.

Saller, E., Laue, H., Schlafli Oppenberg, H. R. \& Cook, A. M. (1995). Purification and some properties of $(1 R, 2 S)$-dihydroxy-3,5cyclohexadiene-1,4-dicarboxylate dehydrogenase from Comamonas testosteroni T-2. FEMS Microbiol Lett (in press).

Sauber, K., Fröhner, C., Rosenberg, G., Eberspächer, J. \& Lingens, F. (1977). Purification and properties of pyrazon dioxygenase from pyrazon-degrading bacteria. Eur J Biochem 74, 89-97.

Schlafli, H. R., Weiss, M., Leisinger, T. \& Cook, A. M. (1994). Terephthalate 1,2-dioxygenase system from Comamonas testosteroni T-2: purification and some properties of the oxygenase component. $J$ Bacteriol 176, 6644-6652.

Stanier, R. Y. \& Ornston, L. N. (1973). The $\beta$-ketoadipate pathway. Adv Microb Pbysiol 9, 89-151. 
Tan, H.-M. \& Fong, K. P. Y. (1993). Molecular analysis of the plasmid-borne bed gene cluster from Pseudomonas putida ML2 and cloning of the cis-benzene dihydrodiol dehydrogenase gene. Can J Microbiol 39, 357-362.

Tan, H.-M., Joannou, C. L., Cooper, C. E., Butler, C. S., Cammack, R. \& Mason, J. R. (1994). The effect of ferredoxin ${ }_{B E D}$ overexpression on benzene dioxygenase activity in Pseudomonas putida ML2. $J$ Bacteriol 176, 2507-2512.

Thurnheer, T., Köhler, T., Cook, A. M. \& Leisinger, T. (1986). Orthanilic acid and analogues as carbon sources for bacteria: growth physiology and enzymic desulphonation. $J$ Gen Microbiol 132, 1215-1220.

Thurnheer, T., Zürrer, D., Höglinger, O., Leisinger, T. \& Cook, A. M. (1990). Initial steps in the degradation of benzene sulfonic acid, 4-toluene sulfonic acid and orthanilic acid in Alcaligenes sp. strain O-1. Biodegradation 1, 54-63.

Tonge, G. M., Harrison, D. E. F. \& Higgins, I. J. (1977). Purification and properties of the methane mono-oxygenase enzyme system from Methylosinus trichosporium OB3b. Biocbem J 161, 333-344.

Wackett, L. P. (1990). Toluene dioxygenase from Pseudomonas putida F1. Methods Engymol 188, 39-45.

Whited, G. M. \& Gibson, D. T. (1991). Separation and partial characterization of the enzymes of the toluene-4-monooxygenase pathway in Pseudomonas mendocina KR1. J Bacteriol 173, 3017-3020.

Yamaguchi, M. \& Fujisawa, H. (1978). Characterization of NADHcytochrome reductase, a component of benzoate 1,2-dioxygenase system from Pseudomonas arvilla C-1. J Biol Chem 253, 8848-8853.

Zylstra, G. J. \& Gibson, D. T. (1989). Toluene degradation by Pseudomonas putida $\mathrm{F} 1$ : nucleotide sequence of the todC1C2BADE genes and their expression in Escherichia coli. J Biol Chem 264, 14940-14946.

Received 30 January 1995; revised 18 May 1995; accepted 22 May 1995. 